\title{
The Role of Abortion in the Last Stage Of Fertility Decline in Vietnam
}

By Bussarawan Teerawichitchainan and Sajeda Amin

Bussarawan Teerawichitchainan is assistant professor, School of Social Sciences, Singapore Management University,

Singapore, and Sajeda Amin is senior associate, Program on Poverty, Gender, and Youth, Population Council, New York.
CONTEXT: Vietnam has experienced a rapid fertility decline over the last three decades, yet fertility rates vary considerably across the country's 54 ethnic groups.

METHODS: Data were drawn from the 2001 Vietnam National Health Survey, which collected information from 27,097 currently married women aged 15-49 on their birth and abortion history over the preceding five years, as well as their current contraceptive use. Multivariate regression analyses identified associations between individual, household and community characteristics and women's contraceptive use and abortion history, and examined ethnic differences in the types of methods used and in abortion incidence.

RESULTS: Vietnam's total fertility rate was 1.6 children per woman, whereas the rate among ethnic minorities in the northern uplands and central highlands was 2.6 and 2.8, respectively. These groups also had a lower abortion rate than the national average (0.3-0.5 vs.0.7), and were less likely than the group comprising the Kinh majority and the Chinese minority to have used either a modern or traditional contraceptive (odds ratios, 0.4-0.7) or to have had an abortion (0.2-0.6). The likelihood of having had an abortion was elevated among older (5.6-21.2) and better educated women (1.4-1.7), as well as among those with one or two children and those from socioeconomically advantaged ethnic groups (1.2-1.4). Finally, abortion rates were higher among women who practiced traditional methods than among those who used modern ones.

CONCLUSIONS: Because better access to abortion is unlikely by itself to reduce fertility among high-fertility minority groups, programs that provide supportive reproductive health services and that target young, low-parity and less educated women may help to lower fertility among these groups.

International Perspectives on Sexual and Reproductive Health, 2010, 36(2):80-89
Vietnam's total fertility rate dropped from 5.7 births per woman in 1979 and 3.8 births in $1989^{1}$ to 2.0 for the period 1998-2002, according to the 2002 Demographic and Health Survey, ${ }^{2}$ yet despite this rapid decline, rates vary considerably across the country's 54 ethnic groups. The Kinh, who account for $84 \%$ of the country's population of 86 million, have completed the transition to replacementlevel fertility. ${ }^{3}$ Some ethnic minority groups, such as the Chinese, Tay, Thai, Muong and Nung, have also achieved low levels of fertility, whereas minorities in the northern uplands and central highlands-who tend to be poor and account for three-fourths of Vietnam's ethnic minority population of 14 million people-have not. For example, the Dao and the Hmong-the two most populous minority groups in the northern uplands-had total fertility rates of 3.6 and 7.1, respectively, according to the 1999 census. $^{4}$ While 2006-2008 fertility estimates based on the Population Change and Family Planning Surveys conducted by Vietnam's General Statistics Office suggest that fertility is declining among women in the northern uplands and central highlands, their rates remain well above replacement and are higher than those for women in the lowlands, such as the Red River Delta, who tend to be of Kinh ethnicity. ${ }^{3}$ Furthermore, some minority groups report a significantly higher prevalence of unmet need for family planning than do the Kinh. 2,5 Therefore, before the last stage of fertility decline in Vietnam is attained, the reproductive health and family planning needs of ethnic minorities must be addressed.

Vietnam's rapid fertility decline has been associated with high rates of both contraceptive use and induced abortion. ${ }^{1}$ The latter is primarily provided by the government, free of charge or for a minimal fee, and is available to married women on request at most public health facilities. According to official statistics, the total abortion rate averaged 2.5 procedures per woman in the mid-1990s. ${ }^{6}$ Because of this high rate, abortion is believed to have been adopted as an alternative to contraceptives, particularly among the Kinh and among low-fertility minority groups. ${ }^{7}$ To explore the role of abortion in further fertility decline among high-fertility minority populations in Vietnam, the present study analyzes unique data from the 2001 Vietnam National Health Survey, ${ }^{8}$ and examines ethnic differences in the prevalence and determinants of abortion and contraceptive use using a new classification system for ethnicity that is based on poverty indicators, geographic location and degree of assimilation. Given that ethnic minority groups in Vietnam are disproportionately poor, we 
assess whether ethnic differentials in abortion and contraceptive use can be explained by socioeconomic traits and the accessibility and quality of family planning services in minority communities. Further, the study assesses whether women's use of certain methods correlates with their decision to seek abortion, and the extent to which such correlations vary among ethnic groups.

\section{BACKGROUND}

Vietnam's family planning policy has played an important role in the rapid decline in fertility over the last three decades. A population policy was first formulated in 1963 by the socialist government of North Vietnam. The government planned to lower the annual population growth rate from $3.5 \%$ to $2 \%$ by advising couples to limit their family size to two or three children, with 5-6 years between children. ${ }^{9}$ Because of the scarcity of resources and other disruptions caused by the Vietnam War (19651975), the success of this initial policy was limited, although it did increase the availability of contraceptives and abortion services in North Vietnam. Following the reunification of North and South Vietnam in 1975, the government expanded family planning services in the south, where fertility rates had been higher than in the north and where pronatalist policies had been instituted before the 1970s. In 1988, the government implemented an antinatalist population policy, which called for one or two children per family and 3-5 years between children, as well as free provision of contraceptives and abortion services, cash incentives for sterilization and penalties for violations. ${ }^{10}$ Although the government was strongly motivated to pursue population policies and followed many of the measures adopted by the Chinese government, the policy measures were less draconian.

A key institutional factor in Vietnam's fertility decline was the establishment of the National Council of Population and Family Planning (NCPFP) in 1984. By the late 1980s, the NCPFP had established provincial offices, commune-level branches and networks of village-level family planning promoters. * Rather than using coercion, as had China's family planning campaigns, Vietnam's program appeared to be subtly manipulative. According to an ethnographic study in northern Vietnam, family planning was not entirely voluntary: ${ }^{11}$ Local family planning promoters relied on personal relationships and emphasized economic and normative disincentives toward excessive childbearing to make people feel obligated to have no more than two children.

Until fairly recently, Vietnam's family planning strategy tended to favor the IUD over other methods. ${ }^{12}$ Evidence indicates that teams of health workers who visited villages were expected to meet targets for IUD insertions. This strategy, borrowed from other socialist states, was driven by a lack of resources to provide inexpensive, supplybased contraceptive methods, and by a desire to maintain centralized control over the medical facilities that provided family planning services. ${ }^{6}$ According to the 2002 De- mographic and Health Survey, virtually all Vietnamese women of reproductive age knew of at least one contraceptive method, and the IUD was the method most widely known. ${ }^{2}$ Furthermore, the IUD was by far the most commonly used method among currently married women: Sixty-five percent reported that they had ever used the method, while 38\% reported currently using it. Despite the increasing use of other methods (e.g., the pill and condoms), the IUD, which was first imported from Czechoslovakia and China in the 1960s, has remained the most widely used method.

Abortion was also promoted in Vietnam's early family planning campaigns. Since 1989, the government has provided free abortion services to married women of reproductive age who are registered with local family planning promoters. Two categories of pregnancy termination are available: Menstrual regulation (hut thai) refers to a suction procedure performed within five weeks of conception, whereas abortion (nao thai) refers to all other procedures (e.g., manual vacuum aspiration and dilation and curettage) performed after this period. ${ }^{\dagger}$ All possible grounds for pregnancy termination are allowed as long as the procedure is conducted by a health professional. A majority of terminations are provided at public health facilities, which are available in cities, relatively well-off villages and even remote rural areas served by mobile medical teams. Menstrual regulation is generally available at the most fundamental health facilities, such as commune health centers, which provide primary and preventive care throughout the country. Over the last decade, abortions beyond five weeks of conception could be performed only by professionals at district, provincial or tertiary hospitals. Fees for abortion services vary according to the administrative level of the hospital and the province's economic status $^{13}$-from 40,000 Vietnamese dong (VND; US\$2) for a first-trimester abortion to 1.5 million VND (US\$78) for a second-trimester procedure. Married women who experience method failure have access to free abortion services. In poor, rural and mountainous areas, all abortion services are available without charge. Private abortion providers have purportedly become increasingly common following Vietnam's economic reforms in the late 1980s, but the proportion of all abortions performed by such providers is uncertain; in the early 1990s, one study estimated it at 15\%. ${ }^{6}$

Vietnam has one of the world's highest abortion rates. ${ }^{14}$ Although abortion has been available since the 1960s, it was not common until the early 1980s. Its incidence rose rapidly and peaked after the introduction of the one-or-

${ }^{*}$ Communes are third-level administrative units, below provinces and districts; each commune may comprise a number of villages, towns or neighborhoods.

tIn this analysis, unless indicated otherwise, the term "abortion" refers to all of these termination procedures. We did not consider medication abortion, because it became available in Vietnam only recently, and its use is not widespread (sources: Ganatra B et al., From research to reality: the challenges of introducing medical abortion into service delivery in Vietnam, Reproductive Health Matters, 2004, 12(24 Suppl.):105-113; and PATH, Medical abortion in Vietnam: a cost study, 2007, <http://www.path.org/ files/CP_vietnam_med_abt_cost_study_fs.pdf>,accessed Mar.18,2009). 
two-child policy, from 160,000 in 1979 to 810,000 in 1987 and 1.34 million in 1992. ${ }^{10}$ Abortion rates also peaked in the early 1990s, at 100 per 1,000 married women of reproductive age. According to government records, 540,400 abortions were performed in $2003,{ }^{15}$ which suggests a decline over the preceding decade. However, the extent of the decline is uncertain for several reasons: Reporting was incomplete or uncertain, and the growing number of abortions performed in the semiprivate and private sectors (and hence not recorded in administrative records) may have offset the declining number of abortions performed by public providers in recent years. ${ }^{15}$

Government estimates in the mid-1990s suggest that menstrual regulation accounted for $45-60 \%$ of all pregnancy terminations. ${ }^{16}$ One study argued that the high prevalence of abortion in Vietnam was the result of antinatalist population policies and a lack of contraceptive alternatives. ${ }^{6}$ The one-or-two-child policy calls for penalties for third and higher-parity births and for violations of the 3-5-year spacing rule. Although evidence suggests that the government has been less strict about enforcing the rules among populations in remote areas, who tend to belong to ethnic minority groups, fines have been imposed in urban areas and the Red River Delta. ${ }^{11}$ It is possible that penalties may have deterred some women from continuing a pregnancy, but others might have feared abortion procedures beyond five weeks of pregnancy, which are likely perceived to be riskier and more complicated to obtain. Since women were not required to take a pregnancy test prior to undergoing menstrual regulation, they tended to choose menstrual regulation as a precautionary measure even when they were uncertain whether they were pregnant. ${ }^{16}$

Although Vietnamese women report high levels of contraceptive use, recent studies have questioned the useeffectiveness, quality and accessibility of the country's family planning services. ${ }^{17,18}$ While the IUD is the dominant modern method, the use of traditional methods remains widespread. In light of inadequate availability and inefficient use of contraceptives, some researchers argue that Vietnamese women might use abortion to achieve their desired family size, ${ }^{6,7}$ particularly since the procedure is heavily subsidized by the government and many family planning campaigns still list abortion as a method of birth control after the IUD, condom and pill. Whether Vietnam's high-fertility ethnic minority groups will achieve replacement-level fertility in the coming years is unknown. However, a better understanding of the role of abortion in explaining ethnic differentials in fertility outcomes will aid researchers and policymakers in evaluating the prospects for further fertility decline and identifying the reproductive health needs among ethnic minorities.

*The exception is the ethnic Chinese, who account for $1 \%$ of the total pop ulation. Because members of this group usually enjoy high socioeconomic status and reside in urban areas, particularly in Ho Chi Minh City, researchers often combine them with the majority Kinh, as we do in this analysis.

\section{METHODS}

\section{Data Collection}

The 2001 Vietnam National Health Survey (VNHS), conducted by the Ministry of Health and the General Statistics Office, is a population-based, nationally representative data set that provides a unique resource for analyzing ethnic differences in reproductive behaviors. ${ }^{8}$ Data were derived from a three-stage, stratified-cluster, random probability sample of 36,000 households containing nearly 160,000 individuals from 1,200 communes across the country; within these households, all women aged 12-49 who had a husband or a child younger than five were interviewed. The survey collected information on respondents' birth history in the preceding five years, current use of contraceptive methods, and history of unwanted pregnancy, abortion and menstrual regulation in the past five years. We restricted our analyses to 27,097 currently married women aged 15-49, and adjusted for clustering and stratification effects.

The VNHS allows comparison of the reproductive behaviors of the Kinh and of ethnic minorities, as well as comparison across Vietnam's 54 ethnic groups. Despite ample evidence of differences in socioeconomic and cultural characteristics among ethnic minority groups, ${ }^{19}$ most empirical studies lump all minorities into one category,* and thus fail to distinguish the diversity within these populations. Such a crude analytic approach may be driven by a sampling strategy that yields an inadequate number of observations within specific minority groups. Unlike other surveys, however, the VNHS allows us to construct a new classification system for ethnicity that captures the characteristics of ethnic minority populations.

\section{Dependent Variables}

We examined two outcome variables. First, current use of a contraceptive method was measured as a categorical variable: whether the respondent or her spouse was using a modern method (the IUD, pill, injectable, implant, condom, diaphragm, gel, foaming tablet or sterilization), a traditional method (periodic abstinence or withdrawal) or no method to space or prevent a birth at the time of the survey. The second outcome variable was the incidence of abortion: It was incorporated as a dummy variable indicating whether a respondent had had an abortion or menstrual regulation within the past five years. Because the VNHS also asked respondents how many times they had had abortions and menstrual regulations between 1997 and 2001, we were able to calculate total abortion rates. Analogous to a total fertility rate, this rate indicates the average number of abortions a woman would be expected to have during her reproductive lifetime, given current age-specific abortion rates.

Because the VNHS provides high-quality information on deliberate pregnancy termination, we explored the use of abortion in detail. Earlier studies on abortion in Vietnam relied primarily on official data compiled from service providers, and the accuracy of these statistics is questionable. ${ }^{6,16}$ These data are funneled upward to the Ministry of 
Health in a hierarchical fashion: Standard forms are filled out by the provincial health departments based on information from public providers that is in turn assembled by district departments. Not only does the collection of such data vary across districts and provinces, but certain districts or provinces may overreport the numbers of abortions performed-which may have occurred especially during the early 1990s-to impress the central administration or to receive additional resources.

Although international experience suggests that the collection of abortion data via household surveys can be problematic, the VNHS used several procedures to ensure the quality of data. ${ }^{20}$ First, only married women were asked about their abortion history. Because termination of unwanted pregnancies is legal and widely available for married women in Vietnam, and stigma against such abortions is minimal, greater accuracy of reporting is likely to be achieved. Second, during data entry, data coders were instructed to cross-check information on unwanted pregnancy, abortion and cost of abortion to identify inconsistencies and possible errors. Finally, a postenumeration survey permitted an assessment of the quality and validity of the VNHS data, and findings suggested only a small discrepancy (7\%) in abortion reporting between the main survey and postenumeration results. ${ }^{* 20}$

\section{Independent Variables}

Ethnicity is a key independent variable, and our classification scheme attempts to address the varying levels of socioeconomic assimilation and economic development among ethnic minorities in different regions of Vietnam. We categorized the sample into five clusters: the Kinh and Chinese; the Tay, Thai, Muong and Nung (TTMN); the ethnic minorities in the south; the ethnic minorities in the northern uplands; and the ethnic minorities in the central highlands. (See the footnote in Table 1 for a breakdown of ethnic minorities by geographic region.)

In addition to ethnicity, other independent variables were assessed: women's age (in five-year age-groups); number of living children (zero, one, two, or three or more); years of schooling $(0,1-5,6-9$, or 10 or more); residence (urban, rural lowland or low mountainous, or rural high mountainous); household wealth status (lowest quintile classified as poor, and all others as less poor); ${ }^{20}$ and frequency of family planning program activities, such as distribution of methods, consultation and outreach, at commune health centers in the past year (more than once per month, monthly, quarterly, or less than once per quarter). The residence and wealth characteristics were used as proxies for geographic and economic accessibility to modern contraceptives and abortion services.

We expected to find high levels of contraceptive use, particularly modern methods, and a high incidence of abortion among older women who had already reached their government-mandated or desired family size. Furthermore, we expected that better educated women would be more likely to use contraceptives, especially modern methods,
TABLE 1. Percentage distribution of currently married women aged 15-49, by ethnicity, according to selected characteristics, Vietnam National Health Survey, 2001

\begin{tabular}{|c|c|c|c|c|c|}
\hline \multirow[t]{2}{*}{ Characteristic } & \multirow{2}{*}{$\begin{array}{l}\text { Kinh and } \\
\text { Chinese } \\
(\mathrm{N}=22,969)\end{array}$} & \multirow{2}{*}{$\begin{array}{l}\text { TTMN† } \\
(\mathrm{N}=2,076)\end{array}$} & \multicolumn{3}{|c|}{ Ethnic minorities $\neq$} \\
\hline & & & $\begin{array}{l}\text { South } \\
(N=418)\end{array}$ & $\begin{array}{l}\text { Northern } \\
\text { uplands } \\
(\mathrm{N}=946)\end{array}$ & $\begin{array}{l}\text { Central } \\
\text { highlands } \\
(\mathrm{N}=688)\end{array}$ \\
\hline \multicolumn{6}{|l|}{ Age } \\
\hline $15-19$ & 1 & 4 & 2 & 7 & 6 \\
\hline $20-24$ & 12 & 16 & 12 & 18 & 23 \\
\hline $25-29$ & 20 & 20 & 21 & 21 & 20 \\
\hline $30-34$ & 20 & 20 & 20 & 18 & 17 \\
\hline $35-39$ & 20 & 19 & 18 & 18 & 13 \\
\hline $40-44$ & 16 & 14 & 15 & 11 & 13 \\
\hline $45-49$ & 11 & 8 & 11 & 6 & 9 \\
\hline \multicolumn{6}{|c|}{ No. of living children } \\
\hline 0 & 6 & 7 & 8 & 10 & 9 \\
\hline 1 & 22 & 18 & 16 & 14 & 14 \\
\hline 2 & 37 & 34 & 26 & 23 & 19 \\
\hline$\geq 3$ & 35 & 40 & 51 & 53 & 58 \\
\hline \multicolumn{6}{|l|}{ Yrs. of schooling } \\
\hline 0 & 4 & 16 & 38 & 66 & 56 \\
\hline $1-5$ & 44 & 49 & 55 & 29 & 38 \\
\hline $6-9$ & 33 & 24 & 5 & 4 & 4 \\
\hline$\geq 10$ & 19 & 11 & 2 & 1 & 2 \\
\hline \multicolumn{6}{|l|}{ Residence } \\
\hline Urban & 25 & 7 & 13 & 3 & 8 \\
\hline \multicolumn{6}{|l|}{ Rural lowland/low } \\
\hline mountainous & 69 & 29 & 85 & 14 & 13 \\
\hline \multicolumn{6}{|l|}{ Rural high } \\
\hline mountainous & 5 & 63 & 1 & 83 & 80 \\
\hline \multicolumn{6}{|c|}{ Household wealth status§ } \\
\hline Poor & 13 & 51 & 34 & 78 & 91 \\
\hline Less poor & 87 & 49 & 66 & 22 & 9 \\
\hline \multicolumn{6}{|c|}{ Frequency of family planning activities in last yeart† } \\
\hline >once per month & 68 & 47 & 68 & 43 & 42 \\
\hline Monthly & 22 & 16 & 24 & 16 & 23 \\
\hline Quarterly & 3 & 12 & 5 & 16 & 14 \\
\hline <once per quarter & 7 & 24 & 3 & 25 & 20 \\
\hline Total & 100 & 100 & 100 & 100 & 100 \\
\hline
\end{tabular}

†TTMN=Tay, Thai, Muong and Nung. These four ethnic groups are considered separately from the other minorities because they have fertility and abortion rates similar to those of the Kinh majority. \#Ethnic minorities in the south:Khmer, Cham, Xtieng and Cho-ro; in the northern uplands:Hmong, Dao, Ngai,San Chay, San Diu, Giay, Kho-mu, Khang, Xinh-mun, Ha Nhi, Lao, La Chi, La Ha, Phu La, La Hu, Lu, Lo Lo, Mang, Pa Then, Co Lao, Cong, Bo Y, Si La and Pu Peo; and in the central highlands: Gia-rai, Ede, Ba Na, Xo-dang, Co Ho, Mnong, Gie Trieng, Ma, Chu Ru, Brau, Ro Mam, Hre, Ra-glai, Bru Van Kieu, Tho, Cotu, Co, Ta-oi, Chut and O-du. §Households in the lowest quintile were classified as "poor," and all others were classified as "less poor." ++ Includes routine distribution of the pill or condoms, consultations, outreach activities and mobile clinics.

and less likely to resort to abortion for birth control, than would women with less education. We also hypothesized that residents of urban and of rural lowland and low mountainous areas would have greater access to reproductive health services than those living in high mountainous areas, as would women from less poor households compared with those classified as poor. According to Bongaarts and Westoff, ${ }^{21}$ increased access to family planning services will generally lead to rising use of modern methods and, in turn, reduced incidence of unwanted pregnancies and

\footnotetext{
*The postenumeration survey did not use a random sampling of communes; rather, locations were selected on the basis of subjective assessments from field visits and reports of regional supervisors. Because some communes whose data were questionable were chosen, these areas were more likely to reveal a greater discrepancy between the original and postenumeration surveys than were other survey areas (source:reference 20).
} 
TABLE 2. Age-specific and total fertility rates (TFRs) among currently married women, by ethnicity, 1997-2001

\begin{tabular}{|c|c|c|c|c|c|c|}
\hline \multirow{2}{*}{$\begin{array}{l}\text { Age- } \\
\text { group }\end{array}$} & \multirow[t]{2}{*}{ All } & \multirow{2}{*}{$\begin{array}{l}\text { Kinh } \\
\text { and } \\
\text { Chinese }\end{array}$} & \multirow{2}{*}{ TTMN† } & \multicolumn{3}{|c|}{ Ethnic minorities } \\
\hline & & & & South & $\begin{array}{l}\text { Northern } \\
\text { uplands }\end{array}$ & $\begin{array}{l}\text { Central } \\
\text { highlands }\end{array}$ \\
\hline $15-19$ & 0.03 & 0.02 & 0.06 & 0.01 & 0.10 & 0.08 \\
\hline $20-24$ & 0.34 & 0.32 & 0.50 & 0.28 & 0.57 & 0.52 \\
\hline $25-29$ & 0.55 & 0.54 & 0.58 & 0.58 & 0.70 & 0.61 \\
\hline $30-34$ & 0.37 & 0.36 & 0.29 & 0.39 & 0.46 & 0.58 \\
\hline $35-39$ & 0.21 & 0.20 & 0.11 & 0.27 & 0.33 & 0.51 \\
\hline 40-44 & 0.08 & 0.07 & 0.04 & 0.15 & 0.21 & 0.33 \\
\hline $45-49$ & 0.03 & 0.02 & 0.03 & 0.05 & 0.26 & 0.18 \\
\hline TFR & 1.59 & 1.54 & 1.62 & 1.73 & 2.63 & 2.80 \\
\hline
\end{tabular}

†TTMN=Tay, Thai, Muong and Nung. These four ethnic groups are considered separately from the other minorities because they have fertility and abortion rates similar to those of the Kinh majority. $\neq$ See Table 1.

abortion. Finally, because the quality of family planning programs may have significant implications for women's contraceptive use and their decision to seek an abortion, we hypothesized that a higher frequency of program implementation would reflect greater accessibility and, to a certain extent, quality of services, which in turn would lead to increased use of modern methods and reduced risk of unwanted pregnancy and abortion.

\section{Analysis}

Age-specific fertility rates and incidence of abortion, as well as total fertility and abortion rates, were calculated for the five ethnic categories for the period 1997-2001. Use of modern or traditional methods by ethnic category was also assessed, as was use of specific methods among all respondents and among those who had had an abortion in the five years preceding the survey.

Multivariate regression analyses were used to identify associations between individual, household and community characteristics and women's contraceptive use and abortion history. We employed a maximum-likelihood multinomial logistic regression model to examine correlations between selected characteristics and use of either modern or traditional methods, using contraceptive nonuse as the reference category.

Factors associated with having had an abortion were determined using binary logistic regression models. The first

\begin{tabular}{|c|c|c|c|c|}
\hline Ethnic group & $\begin{array}{l}\text { Modern } \\
\text { methodt }\end{array}$ & $\begin{array}{l}\text { Traditional } \\
\text { method } \neq\end{array}$ & None & Total \\
\hline Kinh and Chinese & 59 & 21 & 20 & 100 \\
\hline \multirow{2}{*}{\multicolumn{5}{|c|}{ Ethnic minorities †† }} \\
\hline & & & & \\
\hline South & 56 & 17 & 27 & 100 \\
\hline Northern uplands & 54 & 8 & 38 & 100 \\
\hline Central highlands & 55 & 10 & 36 & 100 \\
\hline
\end{tabular}

tIncludes the IUD, pill, injectable, implant, condom, diaphragm, spermicida gel, foaming tablet and sterilization. \#Includes periodic abstinence and withdrawal. §TTMN=Tay, Thai, Muong and Nung. These four ethnic groups are considered separately from the other minorities because they have fertility and abortion rates similar to those of the Kinh majority. $+\dagger$ See Table 1. model included ethnicity only; the second added respondents' age; the third added years of schooling and number of living children; and the fourth incorporated residence, household wealth and frequency of family planning program activities. The exponentiated coefficients are presented as the odds ratios for whether women had had an abortion in the preceding five years.

\section{RESULTS}

\section{Sample Characteristics}

The Kinh and Chinese accounted for $85 \%$ of the surveyed population, and the Tay, Thai, Muong and Nung made up $8 \%$. Although these four ethnic minorities reside predominantly in Vietnam's northern uplands, they tend to be more similar economically to the Kinh majority than to other minority groups in that region. Ethnic groups in the south accounted for $1.5 \%$ of the VNHS sample, minorities in the northern uplands (including the Dao and Hmong) for $3.5 \%$ and minorities in the central highlands-among the poorest in Vietnam-for $2.5 \%$.

The proportion of married women who were younger than 25 was higher among minorities in the northern uplands (25\%) and the central highlands (29\%) than among the three other ethnic groups (13\%-20\%; Table 1, page 83). Among the Kinh and Chinese, 35\% of women had three or more children, whereas this proportion was $40 \%$ among the Tay, Thai, Muong and Nung and even higher among minority women in the south (51\%), the northern uplands (53\%) and the central highlands (58\%). On average, Kinh and Chinese women had received more years of schooling than had women in other ethnic groups; indeed, although only $4 \%$ and $16 \%$ of the Kinh and Chinese and the TTMN, respectively, had had no schooling, this proportion was dramatically higher among the ethnic minorities grouped by geographic region (38\%-66\%). Regarding area of residence, a much larger proportion of the Kinh and Chinese than of their minority counterparts were urban dwellers (25\% vs. 3-13\%). Furthermore, only $13 \%$ of the Kinh and Chinese were classified as poor, whereas much higher proportions of ethnic minorities, particularly those in the northern uplands and central highlands (78\% and 91\%), fell into this category. Finally, a majority of the women in the VNHS sample lived in communities in which various family planning services were provided at least monthly; this was especially true for the Kinh and Chinese and the ethnic minorities in the south.

\section{Fertility Rates}

There was considerable variation in total fertility rates, as well as in age-specific rates, across the five ethnic categories (Table 2). ${ }^{22}$ All minority groups, particularly those in the northern uplands and central highlands, had higher total fertility rates than the Kinh and Chinese ( 2.6 and 2.8 births per woman for the northern uplands and central highlands groups, respectively, vs. 1.5 births; national average, 1.6 births). Absolute differences in age-specific fertility rates were negligible for the youngest age-group, but differentials 
TABLE 4. Age-specific and total abortion rates (TARs) among currently married women, by ethnicity, 1997-2001

\begin{tabular}{|c|c|c|c|c|c|c|}
\hline \multirow{2}{*}{$\begin{array}{l}\text { Age- } \\
\text { group }\end{array}$} & \multirow[t]{2}{*}{ All } & \multirow{2}{*}{$\begin{array}{l}\text { Kinh } \\
\text { and } \\
\text { Chinese }\end{array}$} & \multirow[t]{2}{*}{ TTMN† } & \multicolumn{3}{|c|}{ Ethnic minoritiesł } \\
\hline & & & & South & $\begin{array}{l}\text { Northern } \\
\text { uplands }\end{array}$ & $\begin{array}{l}\text { Central } \\
\text { highlands }\end{array}$ \\
\hline 15-19 & 0.01 & 0.01 & 0.00 & 0.00 & 0.01 & 0.00 \\
\hline $20-24$ & 0.08 & 0.08 & 0.09 & 0.00 & 0.03 & 0.02 \\
\hline $25-29$ & 0.14 & 0.14 & 0.20 & 0.09 & 0.13 & 0.05 \\
\hline $30-34$ & 0.15 & 0.16 & 0.18 & 0.15 & 0.08 & 0.03 \\
\hline $35-39$ & 0.14 & 0.14 & 0.13 & 0.10 & 0.13 & 0.02 \\
\hline $40-44$ & 0.11 & 0.11 & 0.13 & 0.12 & 0.07 & 0.18 \\
\hline $45-49$ & 0.05 & 0.05 & 0.07 & 0.04 & 0.04 & 0.00 \\
\hline TAR§ & 0.67 & 0.68 & 0.80 & 0.49 & 0.49 & 0.30 \\
\hline
\end{tabular}

TTTMN=Tay, Thai, Muong and Nung. These four ethnic groups are considered separately from the other minorities because they have fertility and abortion rates similar to those of the Kinh majority. ¥See Table 1. §Average number of abortions a woman would have over her reproductive lifetime, given current age-specific abortion rates.

emerged among 20-24-year-olds and remained across most of the older age categories; overall, the ethnic fertility differentials were driven by the large differences between the Kinh and Chinese and minorities in the northern uplands and central highlands beginning with the 20-24 agegroup. The age-specific pattern of the Tay, Thai, Muong and Nung minorities, who are most similar to the Kinh and Chinese in total fertility, was particularly distinctive in having high fertility rates among 20-29-year-olds and dramatically lower rates among those older than 30 .

\section{Contraceptive Use}

Fifty-nine percent of women reported using a modern method at the time of the survey, whereas $20 \%$ used a traditional method and 21\% used none (not shown). High proportions of women in every ethnic grouping reported currently using a modern contraceptive (Table 3): Tay, Thai, Muong and Nung women reported the highest prevalence $(70 \%)$, while the other four ethnic groups ranged from $54 \%$ to $59 \%$. The IUD was the most commonly used modern contraceptive in all ethnic groups, particularly among minorities in the northern uplands, where nearly $80 \%$ of women using a modern method reported relying on the IUD (not shown). Other common methods were the pill, female sterilization and the condom.

More than one-fifth of Kinh and Chinese women were using a traditional method at the time of the survey; the other ethnic groupings reported lower proportions using such methods (8-17\%). Contraceptive nonuse was substantial among the high-fertility minority groups in the northern uplands (38\%) and central highlands (36\%). Among all the other groups, which had already reached replacement-level fertility, nonuse was reported by 19$27 \%$ of surveyed women.

*Because the official abortion statistics were likely inflated, the actual decline may be less steep than implied from a direct comparison of administrative data from the 1990s with abortion rates derived from the VNHS and the Vietnam Demographic and Health Survey. Furthermore, although women may generally underreport abortions in surveys, we believe that, given how the data were collected and processed in the VNHS, underreporting does not represent a major problem.

\section{Abortion Rates}

Some $12 \%$ of women reported having had at least one abortion or menstrual regulation during 1997-2001 (not shown). On average, a married woman in Vietnam had 0.67 abortions during her reproductive years (Table 4). This estimate is comparable to the total abortion rate of 0.6 based on the 2002 Vietnam Demographic and Health Survey, ${ }^{2}$ but significantly lower than the rate of 2.5 abortions derived from service providers' data. ${ }^{* 6}$ The total abortion rate was highest among Tay, Thai, Muong and Nung women (0.8), who also reported the highest use of modern contraceptives; the rate was lower for the Kinh and Chinese (0.7), and lowest among ethnic minorities in the

\begin{tabular}{|c|c|c|}
\hline Characteristic & $\begin{array}{l}\text { Modern } \\
\text { method } †\end{array}$ & $\begin{array}{l}\text { Traditional } \\
\text { method } \neq\end{array}$ \\
\hline \multicolumn{3}{|l|}{ Ethnicity } \\
\hline Kinh and Chinese (ref) & 1.00 & 1.00 \\
\hline TTMN§ & $1.54(0.12)^{* * *}$ & $0.78(0.08)^{*}$ \\
\hline \multicolumn{3}{|l|}{ Ethnic minorities†† } \\
\hline South & $0.81(0.10)$ & $0.76(0.12)$ \\
\hline Northern uplands & $0.74(0.08)^{* *}$ & $0.38(0.06)^{* * *}$ \\
\hline Central highlands & $0.68(0.07)^{* * *}$ & $0.44(0.07)^{* * *}$ \\
\hline \multicolumn{3}{|l|}{ Age } \\
\hline$<20$ (ref) & 1.00 & 1.00 \\
\hline $20-24$ & $3.53(0.44)^{* * *}$ & $1.92(0.36)^{* *}$ \\
\hline $25-29$ & $8.02(0.98)^{* * *}$ & $4.98(0.92)^{* * *}$ \\
\hline $30-34$ & $14.52(1.80)^{* * *}$ & $9.78(1.81)^{* * * *}$ \\
\hline $35-39$ & $24.76(3.14)^{* * *}$ & $19.89(3.70)^{* * *}$ \\
\hline $40-44$ & $19.78(2.51)^{* * *}$ & $20.54(3.82)^{* * *}$ \\
\hline $45-49$ & $5.53(0.69)^{* * * *}$ & $8.25(1.53)^{* * *}$ \\
\hline \multicolumn{3}{|l|}{ Yrs. of education } \\
\hline 0 (ref) & 1.00 & 1.00 \\
\hline $1-5$ & $1.41(0.09)^{* * *}$ & $1.83(0.16)^{* * *}$ \\
\hline $6-9$ & $1.61(0.11)^{* * *}$ & $1.97(0.19)^{* * * *}$ \\
\hline$\geq 10$ & $1.27(0.10)^{* *}$ & $1.61(0.16)^{* * *}$ \\
\hline \multicolumn{3}{|l|}{ No. of living children } \\
\hline 0 (ref) & 1.00 & 1.00 \\
\hline 1 & $1.30(0.07)^{* * *}$ & $1.82(0.11)^{* * * *}$ \\
\hline 2 & $2.55(0.11)^{* * *}$ & $2.88(0.15)^{* * *}$ \\
\hline$\geq 3$ & $0.92(0.07)$ & $0.91(0.09)$ \\
\hline \multicolumn{3}{|l|}{ Residence } \\
\hline Urban (ref) & 1.00 & 1.00 \\
\hline Rural lowland/low mountainous & $1.23(0.05)^{* * *}$ & $1.12(0.05)^{*}$ \\
\hline Rural high mountainous & $1.20(0.08)^{*}$ & $1.20(0.10)^{*}$ \\
\hline \multicolumn{3}{|l|}{ Household wealth statusł‡ } \\
\hline Poor & $1.07(0.05)$ & $0.84(0.05)^{* *}$ \\
\hline Less poor (ref) & 1.00 & 1.00 \\
\hline \multicolumn{3}{|c|}{ Frequency of family planning activities in last year§§ } \\
\hline <once per quarter (ref) & 1.00 & 1.00 \\
\hline Quarterly & $1.09(0.10)$ & $0.91(0.10)$ \\
\hline Monthly & $1.11(0.07)$ & $0.98(0.08)$ \\
\hline >once per month & $1.13(0.07)$ & $0.96(0.07)$ \\
\hline
\end{tabular}

${ }^{*} \mathrm{p}<.05 .{ }^{* *} \mathrm{p}<.01 .{ }^{* * *} \mathrm{p}<.001$. Includes the IUD, pill, injectable, implant, condom, diaphragm, spermicidal gel, foaming tablet and sterilization. ‡Includes periodic abstinence and withdrawal. §TTMN=Tay, Thai, Muong and Nung. These four ethnic groups are considered separately from the other minorities because they have fertility and abortion rates similar to those of the Kinh majority. $+†$ See Table $1 . \neq \neq$ Households in the lowest quintile were classified as "poor," and all others were classified as "less poor." §§Includes routine distribution of the pill or condoms, consultations, outreach activities and mobile clinics. Note: ref=reference category. 
TABLE 6. Odds ratios (and standard errors) from binary logistic regressions to identify associations between selected characteristics and having had an abortion in 1997-2001

\begin{tabular}{l} 
Characteristic \\
\hline Ethnicity \\
Kinh and Chinese (ref) \\
TTMN + \\
Ethnic minorities $\neq$ \\
$\quad$ South \\
$\quad$ Northern uplands \\
Central highlands \\
Age \\
$<20$ (ref) \\
$20-24$ \\
$25-29$ \\
$30-34$ \\
$35-39$ \\
$40-44$ \\
$45-49$ \\
Yrs. of education \\
0 (ref) \\
$1-5$ \\
$6-9$ \\
$\geq 10$
\end{tabular}

Model $1 \quad$ Model $2 \quad$ Model $3 \quad$ Model 4

No. of living children

0 (ref)

1

2

$\geq 3$

Residence

\subsection{0}

$1.22(0.08)^{* *}$

$0.79(0.13)$

$0.61(0.08)^{* * *}$

$0.15(0.04)^{* * *}$
1.00

$1.23(0.08)^{* * *}$

$0.79(0.14)$

$0.64(0.08)^{* * *}$

$0.16(0.04)^{* * *}$

$1.00 \quad 1.00$

$1.32(0.09)^{* * *} \quad 1.24(0.10)^{* *}$

$1.03(0.18) \quad 1.05(0.18)$

$0.86(0.12) \quad 0.79(0.12)$

$0.22(0.06)^{* * *} \quad 0.20(0.06)^{* * * *}$

$\begin{array}{llcc}\text { na } & 1.00 & 1.00 & 1.00 \\ \text { na } & 9.83(4.99)^{* * *} & 8.94(4.54)^{* * *} & 9.06(4.61)^{* * *} \\ \text { na } & 19.84(10.00)^{* * *} & 16.09(8.1)^{* * *} & 16.45(8.30)^{* * *} \\ \text { na } & 21.20(10.68)^{* * *} & 16.73(8.44)^{* * *} & 17.13(8.64)^{* * *} \\ \text { na } & 18.28(9.21)^{* * *} & 15.02(7.58)^{* * *} & 15.39(7.77)^{* * *} \\ \text { na } & 13.64(6.88)^{* * *} & 11.80(5.96)^{* * *} & 12.09(6.11)^{* * *} \\ \text { na } & 6.01(3.05)^{* * *} & 5.63(2.87)^{* *} & 5.80(2.96)^{* *}\end{array}$

na
na
na
na

na

na

na

$\begin{array}{ll}\text { na } & \text { na } \\ \text { na } & \text { na } \\ \text { na } & \text { na } \\ \text { na } & \text { na }\end{array}$

na

na

na

\section{na}

na

na
Urban (ref)

Rural lowland/

low mountainous

Rural high mountainous

Household wealth status§

Poor household

Less poor (ref) na

Frequency of family planning activities in last yeart†

<once per quarter (ref)

Quarterly

Monthly

>once per month

$d f$

Log-likelihood

na

na

na
na
na

10

$-9257.1$

${ }^{*} \mathrm{p}<.05 .{ }^{* *} \mathrm{p}<.01 .{ }^{* * *} \mathrm{p}<.001$. TTTMN=Tay, Thai, Muong and Nung. These four ethnic groups are considered separately from the other minorities because they have fertility and abortion rates similar to those of the Kinh majority. ¥See Table 1.§Households in the lowest quintile were classified as "poor," and all others were classified as "less poor." +†ncludes routine distribution of the pill or condoms, consultations, outreach activities and mobile clinics. Notes: ref=reference category. na=not applicable. ${ }^{\circ}$

central highlands (0.3) and the south and the northern uplands ( 0.5 each). Across all ethnic groups, abortion was very rare among women younger than 20 and peaked among women in their late 20s and 30s (the exception was among women in the central highlands, whose abortion rate was highest in the 40-44 age-group).

\section{Multivariate Results}

Compared with Kinh and Chinese women, Tay, Thai, Muong and Nung women were more likely to use a modern method, but less likely to use a traditional method, relative to using no contraceptive (odds ratios, 1.5 and 0.8, respectively; Table 5, page 85 ). Minority women in the northern uplands and central highlands were less likely than the Kinh and Chinese to use either a modern method ( 0.7 for each) or a traditional method ( 0.4 for each).

Women's age was one of the most important determinants of current contraceptive use: Respondents older than 20 were more likely than those younger than 20 to use either modern or traditional methods. The odds of using a modern method relative to nonuse of contraceptives peaked among women aged 35-39 (odds ratio, 24.8), whereas the odds of using a traditional method peaked among those aged 40-44 (20.5). In addition, women with any education were more likely than those with none to have used either a modern or a traditional method (1.3-1.6 and 1.6-2.0, respectively), regardless of how many years of schooling they had.

Women who had one or two living children were more likely than those with none to use either modern or traditional methods instead of no method (odds ratios, 1.3-2.6 and 1.8-2.9, respectively). Respondents who lived in rural lowland or low mountainous areas, as well as those in rural high mountainous areas, were more likely than urban dwellers to use either a modern method (1.2 for each) or a traditional method (1.1-1.2). Finally, women who lived in poor households were less likely than those in less poor households to use a traditional method instead of no method (0.8).

Significant differences in women's odds of having had an abortion in 1997-2001 were found between the Kinh and Chinese and three of the four other ethnic groupings (Table 6). Tay, Thai, Muong and Nung women were more likely than Kinh and Chinese women to have had an abortion (odds ratio, 1.2), whereas women in the central highlands and northern uplands were less likely to report abortions (0.2 and 0.6, respectively).

When respondents' age was added to ethnicity in model 2 , it was strongly correlated with having had an abortion: Women in the age-groups between 20 and 49 were more likely than those younger than 20 to report obtaining an abortion (odds ratios, 6.0-21.2). However, age did not alter the relationship between ethnicity and abortion.

In model 3, when educational attainment and number of living children were added, the risk of having had an abortion was significantly higher among women with 6-9 years or 10 or more years of education than among those with no schooling (odds ratios, 1.4 and 1.6, respectively), and was also higher among women with one or two living children than among those with none (1.2 and 1.4, respectively). The odds of abortion among the Tay, Thai, Muong and Nung rose slightly in relationship to those among the Kinh and Chinese (1.3), but remained similar in the central highlands grouping (0.2); the odds in the northern uplands grouping lost significance. The relationship of age to the risk of abortion declined modestly but remained significant when the two new characteristics were added (5.6-16.7).

With the addition of community factors in model 4, location of residence and household wealth status made no difference; however, women living in communities where 
family planning program activities occurred at least quarterly were less likely to have an abortion than those living in communities with less frequent program activities (odds ratios, 0.7-0.8). However, although the odds of having had an abortion among the TTMN grouping decreased slightly in relation to those among the Kinh and Chinese (1.2), the odds among other ethnic groupings remained similar to those in previous models ( 0.2 for minorities in the central highlands), as did the results according to age (5.8-17.1), educational attainment (1.4-1.7) and number of living children (1.2-1.4).

\section{Links Between Contraceptive Use and Abortion}

In light of several studies that have suggested that increased contraceptive use may play a role in reducing abortion rates, ${ }^{21,23}$ we used the VNHS data to examine this possible relationship. However, we could not determine whether this relationship was causal, because the VNHS asked respondents only about their current method of contraception, not about the methods used before each pregnancy termination.

Overall, current users of a modern method reported lower abortion incidence than those who used a traditional method ( $12 \%$ vs. 18\%; not shown). However, substantial variations were seen among users of different modern methods, suggesting low use-effectiveness for some methods. For example, among IUD users-more than onethird of all married women in the sample-9\% had at least one abortion between 1997 and 2001, whereas abortion incidence was higher for users of the pill (18\%) and the condom (20\%). In contrast, women who used a traditional method-who accounted for one-fifth of the sample-reported consistently high rates of abortion: $17 \%$ for those who used the rhythm method and 19\% for those who practiced withdrawal. These findings suggest a linkage between use of traditional methods and use of abortion among married women in Vietnam.

\section{DISCUSSION}

Our analyses reveal two noteworthy patterns of reproductive behavior among married Vietnamese women that explain ethnic differences in fertility outcomes. The first pattern is observed among low-fertility populations, such as the Kinh and Chinese, the Tay, Thai, Muong and Nung, and, to a certain extent, ethnic minorities in the south. These population groupings had relatively low rates of contraceptive nonuse, and while the TTMN group had an especially high rate of modern method use, the Kinh and Chinese and the minorities in the south had the highest rates of traditional method use, as well as high rates of modern use. The second pattern reflects the experience of the two high-fertility groups-minorities in the northern uplands and central highlands. Although their use of modern contraceptives was comparable to that of the Kinh and Chinese, these groups were less likely to use traditional methods or to rely on abortion. Their rates of contraceptive nonuse were also relatively high.
Our findings indicate that the prevalence of abortion is high in Vietnam, but not as high as previously reported on the basis of data from service providers. The present analysis suggests that abortion was more common among married women aged 20 or older, those with more years of schooling and those with one or two children, as well as among women from the Kinh majority group and the more socioeconomically privileged ethnic minorities such as the Chinese, Tay, Thai, Muong and Nung. Although elevated abortion rates among older women and those with one or two children may reflect a cohort phenomenon, we believe the elevated rate among better educated womenwho tend to be younger because of the expansion of primary and lower secondary education after national reunification-may be interpreted as an indicator that abortion is more common among more privileged groups. ${ }^{24}$

This study also shows that the abortion rate was higher among women who used a traditional method than among those who used a modern method. Socioeconomic status explained ethnic differences in the likelihood of having an abortion between minorities in the northern uplands and Kinh and Chinese women: When women's education and household factors were controlled for the former group, the difference lost significance. Meanwhile, the odds of having had an abortion remained consistently high among women in the Tay, Thai, Muong and Nung grouping, and consistently low among minority women in the central highlands.

Our results suggest that service provision strategies should be adapted to meet the particular needs of different high-fertility ethnic groups. In the northern uplands, an appropriate strategy for further fertility decline may be to increase access to education and provide higher-quality abortion services; in the central highlands, where the abortion rate is the lowest, access to abortion is unlikely to reduce the region's relatively high levels of fertility. It is possible that religious factors deter minority groups in this area from getting abortions. Indeed, many minorities in the central highlands were exposed to Catholicism and the influence of French missionaries in the 19th century. ${ }^{25}$ Hence, reproductive health services for these ethnic groups may need to be offered in conjunction with policies and other approaches that improve family planning programs and promote women's education and later childbearing.

\section{Conclusions}

Our findings show that-given the limited choices of modern contraceptive methods in Vietnam-members of more privileged ethnic groups have achieved replacement-level fertility and compliance with the government's one-or-twochild policy by combining the use of traditional methods with recourse to induced abortion. According to anecdotal evidence, many women who use traditional methods consider abortion as a backup to avoid an unwanted birth. ${ }^{13,26}$ Some women choose traditional and natural family planning methods because they believe that such 
methods pose fewer health risks than such modern methods as the IUD, and are just as effective. Although more recently introduced methods, such as the pill and condom, have become widely available in Vietnam, abortion remains common in certain communities. Because many women have inadequate access to supportive reproductive health services, especially counseling on the effective use of different methods, the improved provision of such services is needed. Until such improvements are implemented, high abortion rates in Vietnam will continue to reflect the country's limited contraceptive alternatives.

\section{REFERENCES}

1. Haughton J, Falling fertility in Vietnam, Population Studies, 1997 , 5l(2):203-211

2. Vietnam Committee for Population, Family and Children (VCPFC) and ORC Macro, Vietnam Demographic and Health Survey, 2002, Calverton, MD, USA: VCPFC and ORC Macro, 2003.

3. United Nations Population Fund (UNFPA) Vietnam, Viet Nam Population 2008, Hanoi, Vietnam: UNFPA Vietnam, 2009.

4. General Statistics Office, Census Monograph on Marriage, Fertility, and Mortality in Vietnam: Levels, Trends, and Differentials, Hanoi, Vietnam: Statistical Publishing House, 2001.

5. UNFPA Vietnam, Knowledge and Behavior of Ethnic Minorities on Reproductive Health, Hanoi, Vietnam: UNFPA Vietnam, 2007.

6. Goodkind D, Abortion in Vietnam: measurements, puzzles, and concerns, Studies in Family Planning, 1994, 25(6):342-352.

7. Do TH, Stoeckel J and Nguyen VT, Pregnancy termination and contraceptive failure in Vietnam, Asia-Pacific Population Journal, 1993, 8(4):3-18

8. Ministry of Health and General Statistics Office, Results from the Vietnam National Health Survey 2001-2002, Hanoi, Vietnam: Medical Publishing House, 2003.

9. Vu QN, Population policies and development in Vietnam, in: Jamieson N, Nguyen MH and Rambo AT, eds., The Challenges of Vietnam's Reconstruction, Fairfax, VA, USA: Indochina Institute of George Mason University, 1992, pp. 40-54.

10. Goodkind D, Vietnam's one-or-two-child policy in action, Population and Development Review, 1995, 21(1):85-111.

11. Gammeltoft T, Women's Bodies, Women's Worries: Health and Family Planning in a Vietnamese Rural Community, Richmond, UK: Curzon Press, 1999.

12. Knodel J et al., Why is oral contraceptive use in Vietnam so low? International Family Planning Perspectives, 1995, 21(1):11-18.

13. Do THN, More to demand: abortion in Vietnam, Women in Action, $2008,1: 6-10$

14. Henshaw SK, Singh S and Haas T, The incidence of abortion worldwide, International Family Planning Perspectives, 1999, 25(Suppl.):S30S38.

15. Sedgh $G$ et al., Legal abortion worldwide: incidence and recent trends, International Family Planning Perspectives, 2007, 33(3):106-116.

16. Trinh HV et al., The potential impact of introducing pregnancy testing into menstrual regulation services in Vietnam, International Family Planning Perspectives, 1998, 24(4):165-169.

17. Do M and Koenig M, Effect of family planning services on modern contraceptive method continuation in Vietnam, Journal of Biosocial Science, 2007, 39(2):201-220.

18. Nguyen MT and Dang NA, Accessibility and use of contraceptives in Vietnam, International Family Planning Perspectives, 2002, 28(4): 214-219.

19. Baulch B et al., Ethnic minority development in Vietnam: a socioeconomic development perspective, in: Glewwe P, Agrawal N and Dollar D, eds., Economic Growth, Poverty, and Household Welfare in
Vietnam, Washington, DC: World Bank, 2004, pp. 273-310.

20. Bales S, Technical Documentation for the Vietnam National Health Survey 2001-2002, Hanoi, Vietnam: Ministry of Health and Statistics Sweden International Consulting Office, 2003.

21. Bongaarts J and Westoff CF, The potential role of contraception in reducing abortion, Studies in Family Planning, 2000, 31(3):193-202.

22. Amin $S$ and Teerawichitchainan B, Ethnic fertility differentials in Vietnam and their proximate determinants, Poverty, Gender, and Youth Working Papers, New York: Population Council, 2009, No. 18

23. Marston C and Cleland J, Relationships between contraception and abortion: a review of the evidence, International Family Planning Perspectives, 2003, 29(1):6-13

24. Woodside A, The triumphs and failures of mass education in Vietnam, Pacific Affairs, 1983, 56(3):401-427.

25. Hickey GC, The Major Ethnic Groups of the South Vietnamese Highlands, Santa Monica, CA, USA: RAND, 1964

26. Johansson A et al., Abortion in context: women's experience in two villages in Thai Binh province, Vietnam, International Family Planning Perspectives, 1996, 22(3):103-107.

\section{RESUMEN}

Contexto: Vietnam ha experimentado una rápida disminución de la fecundidad en las últimas tres décadas; sin embargo, las tasas de fecundidad varían considerablemente a través de los 54 grupos étnicos del país.

Métodos: Se obtuvo datos de la Encuesta Nacional de Salud de Vietnam de 2001, la cual recolectó información de 27,097 mujeres casadas, en edades de 15-49 años, sobre su historia de nacimientos y abortos a lo largo de los cinco años precedentes a la encuesta, así como de su actual uso de anticoncepción. A través de análisis de regresión multivariado, se identificó las asociaciones entre las características de las mujeres (individuales, de la familia y de la comunidad) y su historia de uso de anticonceptivos y de abortos; y se examinó las diferencias étnicas en los tipos de métodos usados y en la incidencia de aborto.

Resultados: La tasa global de fecundidad de Vietnam fue de 1.6 hijos por mujer, mientras que la tasa entre las minorías étnicas en las tierras altas del norte y los altiplanos centrales fue de 2.6 y 2.8, respectivamente. Estos grupos también tuvieron una tasa global de aborto más baja que el promedio nacional (0.3-0.5 abortos por mujer durante su vida vs. 0.7); y tuvieron menor probabilidad que el grupo mayoritario Kinh y chino de haber usado ya sea un anticonceptivo moderno o tradicional (razones de momios, 0.4-0.7), o de haber tenido un aborto (0.2-0.6). La probabilidad de haber tenido un aborto fue alta en las mujeres de mayor edad (razones de momios, 5.6-21.2) y mejor educadas (1.4-1.7), así como entre aquellas con uno o dos hijos y las pertenecientes a grupos étnicos aventajados socioeconómicamente (1.2-1.4). Finalmente, las tasas globales de aborto fueron más altas entre las mujeres que usaban métodos anticonceptivos tradicionales, que entre las que usaban métodos modernos.

Conclusiones: Debido a que no es probable que un mejor acceso al aborto reduzca por sí mismo la fecundidad entre los grupos minoritarios de alta fecundidad, los programas que proporcionan servicios amigables de salud reproductiva y que se están dirigidos a mujeres jóvenes, a las de baja paridad y a las de menor nivel educativo, pueden ayudar a disminuir la fecundidad en estos grupos. 


\section{RÉSUMÉ}

Contexte: Le Vietnam enregistre un rapide déclin de fécondité depuis 30 ans, mais les indices varient considérablement parmi les 54 groupes ethniques du pays.

Méthodes: Les données sont extraites de l'enquête nationale de santé 2001 du Vietnam, qui avait recueilli auprès de 27,097 femmes alors mariées de 15 à 49 ans une information relative à leurs antécédents de naissances et avortements durant les cinq années précédentes, ainsi qu'à leur pratique contraceptive courante. Les associations entre les caractéristiques individuelles, de ménage et de communauté et les pratiques contraceptives et antécédents d'avortement des femmes ont été identifiées par analyses de régression multivariées, avec examen des différences ethniques au niveau des types de méthode pratiquée et de l'incidence de l'avortement.

Résultats: Pour l'ensemble du Vietnam, l'indice synthétique de fécondité a été calculé à 1,6 enfant par femme; parmi les minorités ethniques des montagnes du nord et des plateaux $d u$ centre, il s'élève, respectivement, à 2,6 et 2,8. Ces groupes présentent aussi un plus faible indice synthétique d'avortement que la moyenne nationale $(0,3-0,5$ vs 0,7$)$ et sont moins susceptibles que la majorité Kinh et chinoise d'avoir pratiqué une méthode contraceptive moderne ou traditionnelle (rapport de probabilités, 0,4-0,7) ou d'avoir eu recours à l'avortement $(0,2-0,6)$. Le risque d'avoir eu un avortement estélevé chez les femmes plus âgées $(5,6-21,2)$ et mieux instruites $(1,4-1,7)$, ainsi que parmi celles mères de un ou deux enfants et celles issues de groupes ethniques socioéconomiquement favorisés (1,2-1,4). Enfin, la fréquence d'avortement est supérieure chez les femmes qui pratiquent les méthodes traditionnelles que chez les utilisatrices des méthodes modernes.

Conclusions: Un meilleur accès à l'avortement ne réduira vraisemblablement pas, à lui seul, la fécondité parmi les groupes minoritaires à haut indice de fécondité, mais des programmes apportant des services de santé génésique conviviaux et qui ciblent les femmes jeunes, de faible parité et moins instruites pourraient aider à la réduire parmi ces groupes.

\section{Acknowledgments}

This research was supported by the Hewlett Foundation and the MacArthur Foundation. The first author also acknowledges support from the Office of Research, Singapore Management University (C242/MSS8S004). The authors thank Vietnam's Ministry of Health for permission to use the Vietnam National Health Survey.

Author contact:bteerawichit@smu.edu.sg 